Victor David Arockiaraj Mallika Jeslina ${ }^{1 *}$, Suyambulingam Jone Kirubavathy ${ }^{1}$, Abdulhameed Al-Hashem ${ }^{2}$, Susai Santhammal Rajendran ${ }^{3,6}$, RM Joany $^{4}$, Caslav Lacnjevac ${ }^{5}$

${ }^{1}$ Department of Chemistry, PSGR Krishnammal College for Women, Coimbatore, India, ${ }^{2}$ Petroleum Research Centre, Kuwait Institute for Scientific Research, Kuwait, ${ }^{3} P G$ Department of Chemistry, Corrosion Research Centre St. Antony's College of Arts and Sciences for Women Thamaraipadi, Tamil Nadu, India, ${ }^{4}$ Sathyabama University, Department of ECE, Jeppiaar Nagar, Chennai, Tamil Nadu, India, ${ }^{5}$ University of Belgrade, Faculty of Agriculture, Belgrade, Serbia, ${ }^{6}$ Pondicherry University, India.
Scientific paper

ISSN 0351-9465, E-ISSN 2466-2585

UDC: 665.7.038.5:669.141.24:582.27

https://doi.org/10.5937/zasmat2104304J

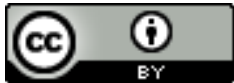

Zastita Materijala 62 (4)

$304-315(2021)$

\title{
Inhibition of corrosion of mild steel by an alcoholic extract of a seaweed Sargassum muticum
}

\begin{abstract}
An alcoholic extract of a sea weed Sargassum muticum has been used to control corrosion of mild steel in $0.5 \mathrm{~N} \mathrm{HCl}$. Weight loss method and Electrochemical studies have been used in this study. Weight loss study reveals that 500 ppm of the inhibitor offers $99.25 \%$ inhibition efficiency. Polarization study reveals that the inhibitor functions as an anodic inhibitor at higher concentration. The AC impedance spectra confirm the formation of a protective film on the metal surface. Adsorption of inhibitor molecules on the metal surface follows Langmuir adsorption isotherm.
\end{abstract}

Keywords: corrosion inhibition, mild steel, sea weed, Sargassum muticum, electrochemical studies, Langmuir adsorption isotherm, acid medium

\section{INTRODUCTION}

Extracts of plant materials are low cost and environmentally friendly. They contain many active ingredients. The molecules of these ingredients may contain hetero or polar atoms such as sulphur $(\mathrm{S})$, nitrogen $(\mathrm{N})$, oxygen $(\mathrm{O})$, phosphorous $(\mathrm{P})$ etc. The lone pair of electrons present on these atoms is pumped on to the metal surface. Thus loss of electrons from the metal surface can be avoided and corrosion inhibition takes place. Because of adsorption of inhibitor molecules on metal surface, protective film is formed on metal surface and corrosion is controlled.

Corrosion is a spontaneous and thermodynamically favourable process. Because of corrosion, every year five percentage GNP of any country is lost. However fifty percentage of corrosion loss can be avoided by the available knowledge. There are many methods used to control corrosion process. One such process is use of inhibitors. Due to their toxic nature chromates, as corrosion inhibitors

${ }^{*}$ Corresponding author: Victor D. A. M. Jeslina

E-mail: jesivictor28@gmail.com

Paper received: 01. 08. 2021.

Paper corrected: 08. 09. 2021.

Paper accepted: 25. 09. 2021.

Paper is available on the website: www.idk.org.rs/journal have been banned by environmental scientists. So researchers are looking for environmental friendly corrosion inhibitors such as extracts of plant materials. Several plant materials have been used for this purpose. [1-10]

Extracts of plant materials contain many active principles. They contain polar atoms such as $\mathrm{S}, \mathrm{N}$, $\mathrm{O}, \mathrm{P}$ etc. Because of this nature, the lone pair of electrons present on these atoms is pumped on to the metal surface. Thus loss of electrons from the metal surface can be avoided. Hence corrosion inhibition takes place. Because of adsorption of inhibitor molecules on metal surface, protective film is formed. Thus corrosion is controlled. Various extracts of plant materials have been used to prevent a variety of metals immersed in various medium at different temperatures in presence and absence of many additives. Many methods have been employed (such as weight loss method, electrochemical studies etc) to evaluate corrosion inhibition efficiencies of inhibitors. The protective film has been analyzed by various surface analyses techniques.

\section{Metals}

Extracts of plant materials have been used to control corrosion of various metals such as steel mild steel [1-9], aluminium and its alloy, zinc and copper. 


\section{Medium}

Extracts of plant materials have been used to prevent corrosion of metals and alloys immersed in various medium such as acidic medium [1,3,5-7] basic medium and neutral medium.

\section{Temperature}

The experiments have been conducted at various temperatures $[8,9]$.

\section{Additives}

Mixture of inhibitors shows better inhibition efficiency than individual members. This is called synergistic effect. For this purpose many additives have been used to improve the inhibition efficiency of plant extracts. For this purpose halide, sulphide and phosphonic acid have been used.

\section{Methods}

To evaluate the corrosion inhibition efficiency of various plant extracts, several methods such as weight loss method [1-4,6] and electrochemical studies (polarization, AC impedance spectra [8]) have been employed.

\section{Surface morphology of protective film}

The protective films formed on metal surfaces have been analyzed by various surface analysis techniques FTIR spectroscopy, UV-Visible spectroscopy, SEM, EDAX and AFM.

\section{Adsorption isotherm}

The protective film formed on the metal surface by adsorption of active principles of various plant extracts on the metal surface. The adsorption isotherms are usually Freundlich adsorption isotherm, Temkin adsorption isotherm and Langmuir adsorption isotherm[ 1,2,5,6].

\section{Thermodynamic parameters}

From the adsorption isotherms various thermodynamic parameters such as changes in free energy, entropy, enthalpy, and activation energy [2] have been calculated.

\section{Plant materials}

Extracts of various parts of the plant have been used as corrosion inhibitors. Fruit leaves [1,5,8], roots, barks, flowers, seeds, stem, gum, husk and peel have been used as corrosion inhibitors.

\section{Extracts}

The plant materials have been extracted by making use of alcohol [1], acid and water [2,3]. Various inhibitors used and methods employed in evaluating their corrosion inhibition efficiencies are summarized in Table1.

In the present study an alcoholic extract of a sea weed, Sargassum muticum, has been used to control corrosion of mild steel in $0.5 \mathrm{~N} \mathrm{HCl}$. Electrochemical studies such as polarization study and $A C$ impedance spectra have been used.

\section{Table 1. Corrosion inhibition by plant extracts}

\section{Tabela 1. Inhibicija korozije biljnim ekstraktima}

\begin{tabular}{|c|c|c|c|c|c|c|c|}
\hline $\begin{array}{l}\text { S. } \\
\text { No }\end{array}$ & Metal & Medium & Inhibitor & $\begin{array}{c}\text { Additive/ } \\
\text { temperature }\end{array}$ & Method & Findings & Ref. \\
\hline 1 & $\begin{array}{l}\text { X60 } \\
\text { carbon } \\
\text { steel }\end{array}$ & $\begin{array}{l}15 \% \mathrm{HCl} \\
\text { solution }\end{array}$ & $\begin{array}{l}\text { Ethanolic } \\
\text { extracts of } \\
\text { date palm } \\
\text { leaves and } \\
\text { seeds }\end{array}$ & & $\begin{array}{l}\text { Weight loss, } \\
\text { electrochemical } \\
\text { Techniques and } \\
\text { photochemical } \\
\text { screening }\end{array}$ & $\begin{array}{c}\text { Inhibition efficiency } \\
\text { increased with increase } \\
\text { in concentration of the } \\
\text { extracts and } \\
\text { temperature. Mixed type } \\
\text { inhibitors. Langmuir } \\
\text { adsorption isotherm } \\
\text { model }\end{array}$ & [1] \\
\hline 2 & $\begin{array}{l}\text { Carbon } \\
\text { steel }\end{array}$ & $\begin{array}{l}\text { Saline formation } \\
\text { water }\end{array}$ & $\begin{array}{c}\text { Centaurea } \\
\text { cyanus } \\
\text { aqueous } \\
\text { extract }\end{array}$ & & $\begin{array}{c}\text { Weight loss } \\
\text { measurements, } \\
\text { electrochemical } \\
\text { impedance } \\
\text { spectroscopy (EIS) } \\
\text { and potentiodynamic } \\
\text { polarization } \\
\text { techniques }\end{array}$ & $\begin{array}{l}\text { Mixed-type inhibitor, } \\
\text { Langmuir adsorption } \\
\text { isotherm }\end{array}$ & [2] \\
\hline 3 & Mild steel & $\begin{array}{l}\mathrm{HCl} \text { aqueous } \\
\text { solution }\end{array}$ & $\begin{array}{l}\text { Gorse } \\
\text { aqueous } \\
\text { extract }\end{array}$ & & $\begin{array}{c}\text { Weight-loss } \\
\text { measurements, } \\
\text { potentiodynamic } \\
\text { polarization curves, } \\
\text { electrochemical } \\
\text { impedance } \\
\text { spectroscopy and } \\
\text { scanning electron } \\
\text { microscopy }\end{array}$ & $\begin{array}{l}\text { Reducing both the } \\
\text { anodic and cathodic } \\
\text { current density }\end{array}$ & [3] \\
\hline
\end{tabular}




\begin{tabular}{|c|c|c|c|c|c|c|c|}
\hline 4. & $\begin{array}{l}\text { Carbon } \\
\text { steel API } \\
5 \mathrm{LX}\end{array}$ & $\begin{array}{l}\text { Hypersaline } \\
\text { environments }\end{array}$ & Neem extract & & $\begin{array}{c}\text { Weight loss, } \\
\text { electrochemical } \\
\text { studies, Fourier } \\
\text { transform infrared } \\
\text { spectroscopy (FT- } \\
\text { IR), X-ray diffraction } \\
\text { spectroscopy (XRD) }\end{array}$ & Inhibit corrosion process & {$[4]$} \\
\hline 5. & Mild steel & $\begin{array}{l}1 \mathrm{M} \mathrm{H} 2 \mathrm{SO} 4 \\
\text { solution }\end{array}$ & $\begin{array}{c}\text { Acacia } \\
\text { cyanophylla } \\
\text { leaves extract }\end{array}$ & & $\begin{array}{l}\text { Polarization } \\
\text { techniques and } \\
\text { electrochemical } \\
\text { impedance } \\
\text { spectroscopy }\end{array}$ & $\begin{array}{l}\text { Mixed inhibitor, } \\
\text { Langmuir isotherm } \\
\text { model }\end{array}$ & {$[5]$} \\
\hline 6. & Mild steel & $\begin{array}{l}\text { Hydrochloric } \\
\text { acid solution }\end{array}$ & $\begin{array}{l}\text { Alpinia } \\
\text { galanga }\end{array}$ & & $\begin{array}{l}\text { Weight loss method, } \\
\text { scanning electron } \\
\text { microscopy }\end{array}$ & $\begin{array}{l}\text { Langmuir adsorption } \\
\text { isotherm }\end{array}$ & {$[6]$} \\
\hline 7. & Mild steel & $\begin{array}{l}15 \text { and } 20 \% \mathrm{HCl} \\
\text { solutions }\end{array}$ & $\begin{array}{l}\text { Coal-tar } \\
\text { distillation } \\
\text { products } \\
\text { [CTDP] and } \\
\text { the aqueous } \\
\text { extract of } \\
\text { ginger } \\
\end{array}$ & & $\begin{array}{c}\text { Weight loss of the } \\
\text { steel }\end{array}$ & $\begin{array}{l}\text { Decrease of corrosion } \\
\text { rate and increase of } \\
\text { inhibition efficiency }\end{array}$ & [7] \\
\hline 8. & $\begin{array}{l}\text { Carbon } \\
\text { steel }\end{array}$ & $\begin{array}{l}\text { Carbon dioxide } \\
\text { saturated } \\
\text { chloride } \\
\text { carbonate } \\
\text { solution }\end{array}$ & $\begin{array}{c}\text { Olive leaf } \\
\text { extract }\end{array}$ & $\begin{array}{c}25^{\circ} \mathrm{C} \text { and } \\
65^{\circ} \mathrm{C}\end{array}$ & $\begin{array}{l}\text { Linear polarization } \\
\text { resistance } \\
\text { technique, } \\
\text { electrochemical } \\
\text { impedance } \\
\text { spectroscopy, } \\
\text { scanning electron } \\
\text { microscopy and } \\
\text { Fourier transform } \\
\text { infrared } \\
\text { spectroscopy }\end{array}$ & $\begin{array}{l}\text { The adsorption of olive } \\
\text { leaf extract on the } \\
\text { carbon steel surface }\end{array}$ & {$[8]$} \\
\hline 9 & Mild steel & 15 wt. $\% \mathrm{HCl}$ & Durum wheat & $\begin{array}{l}\text { Temperatur } \\
\text { e }\left(20-60^{\circ} \mathrm{C}\right) \\
\text { and } \\
\text { immersion } \\
\text { time }(5-24 \mathrm{~h})\end{array}$ & $\begin{array}{c}\text { Weight losses, } \\
\text { Fourier transform } \\
\text { infrared } \\
\text { spectroscopy (FTIR), } \\
\text { SEM, EDS } \\
\text { spectroscopy and } \\
\text { surface profilometry }\end{array}$ & $\begin{array}{l}\text { Langmuir adsorption } \\
\text { isotherm }\end{array}$ & [9] \\
\hline 10 & J55 steel & $\begin{array}{l}\mathrm{CO}_{2} \text {-saturated } \\
3.5 \text { wt. } \% \mathrm{NaCl} \\
\text { solution }\end{array}$ & $\begin{array}{l}\text { Tangerine } \\
\text { peel extract }\end{array}$ & & - & $\begin{array}{c}\text { Mixed type green } \\
\text { inhibitor, the Langmuir } \\
\text { isothermal absorption } \\
\text { model and the El-Awady } \\
\text { dynamic model }\end{array}$ & [10] \\
\hline
\end{tabular}

\section{MATERIALS AND METHODS}

The present investigation deals with the analysis of mild steel corrosion in $0.5 \mathrm{~N} \mathrm{HCl}$ and the inhibitive effect of a seaweed extract (SWE) by weight loss and electrochemical techniques.

\section{Mild steel specimen}

The mild steel specimens used for weight loss and surface examination studies were composed of C - $0.079 \%, \mathrm{P}-0.025 \%, \mathrm{Mn}-0.018 \%$, S - $0.021 \%$ and the remainder $\mathrm{Fe}$ and of dimension $5.0 \mathrm{~cm}$ $x 1.0 \mathrm{~cm} \times 0.05 \mathrm{~cm}$. For electrochemical techniques, mild steel rod of above said composition encapsulated in Teflon with an unprotected area of $1 \mathrm{~cm}^{2}$ was used. Prior to each experiment, the metal specimens were polished to mirror finish with different grades of emery sheets, washed with double distilled water, degreased using acetone; air dried and preserved. All the corrosive electrolytes
$(0.5 \mathrm{~N} \mathrm{HCl})$ were prepared by distilled water and standardized.

\section{Seaweed Extract (SWE) preparation}

The sea weed chosen for the study was identified as Sargassum muticum, Figure 1. The seaweed used for this study was collected from Ramanathapuram, Tamilnadu, India.

Sargassum muticum, commonly known as Japanese wire weed, is a large brown seaweed of the genus Sargassum. It is an invasive seaweed with high growth rate (up to $10 \mathrm{~cm}$ per day during spring). It has an efficient dispersion thanks to its floats [11].

The sea weed was dried completely, powdered and weighed. The extract was prepared by refluxing $5 \mathrm{~g}$ of powdered sea weed in ethanol medium for 8 hours (Figure 2). Then the extract was filtered after one day and placed in an air tight container. 


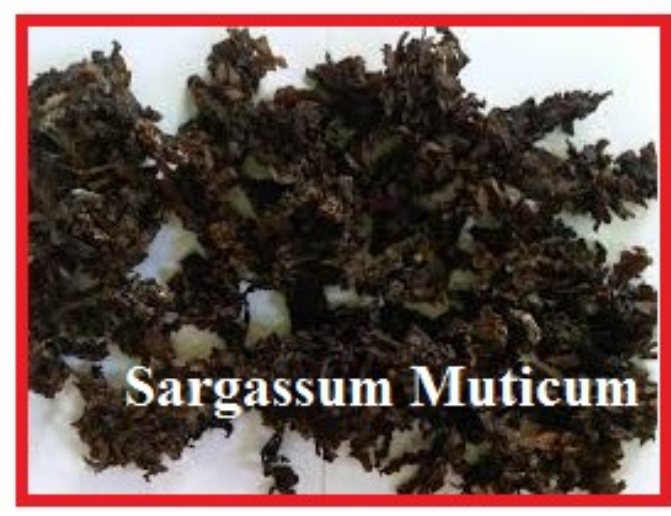

Figure 1: Sargassum muticum

Slika 1: Sargassum muticum

Based on literature review, the Sargassum muticum, was selected for the study due to the presence of the active components. The components of the sea weed extract (Figure 2) of Sargassum muticum was found to contain the following 12 compounds, namely geranyl isovalerate, oleic acid,17-octadecynoic acid, 9,12,15-octadecatrienoic acid, 2,3-dihydroxypropyl ester(zzz), n-hexadecanoic acid, trans-13octadecenoic acid, methyl ester, 6,9,12,15- docosatetraenoic acid, methyl ester, gibberellic acid, fenretinide, 9,10-secocholesta, 5,7,10(19)triene-3,24,25-triol, cholestane-3-01,2-methylene. Structures of some important compounds are shown in Figure3.

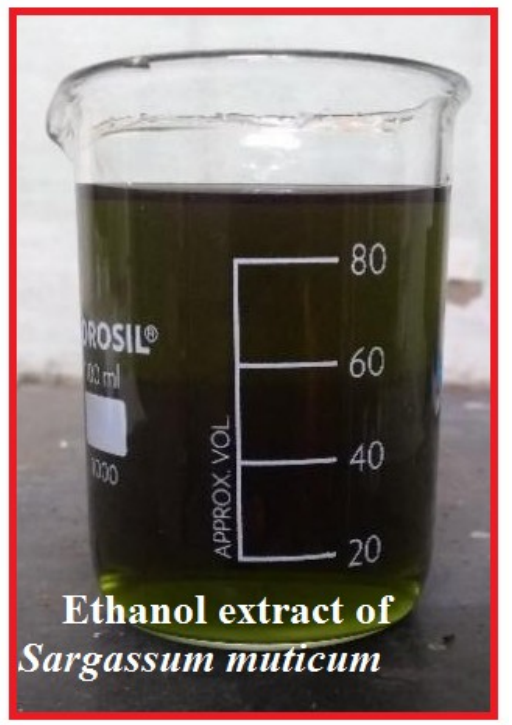

Figure 2: Ethanol extract of Sargassum muticum

Slika 2: Alkoholni ekstrakt Sargassum muticum

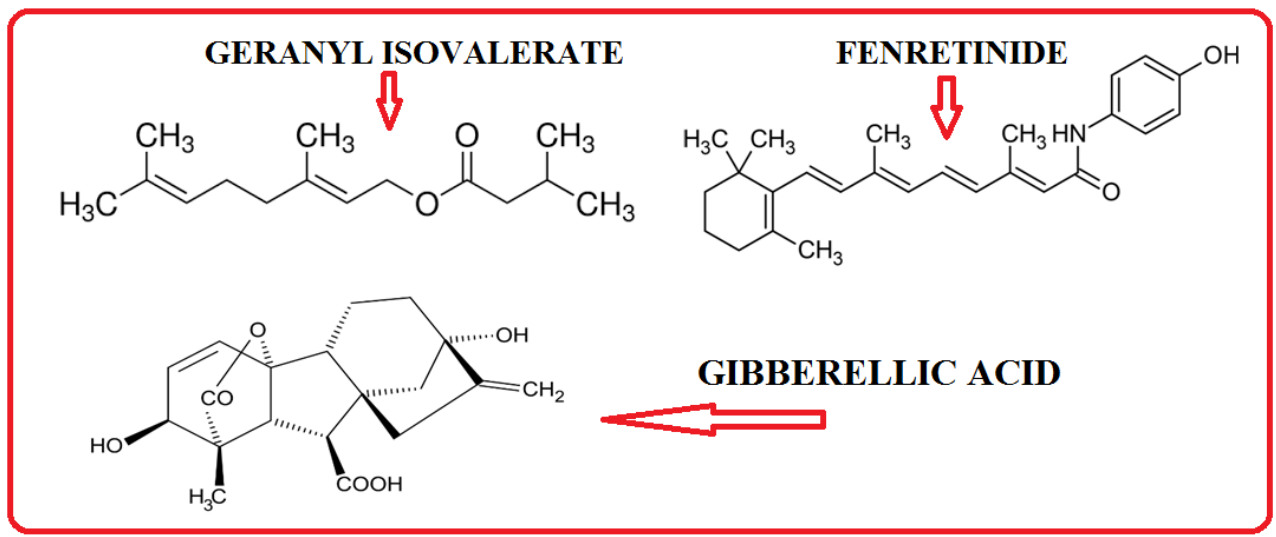

Figure 3. Structures of some important active principles

Slika 3. Strukture nekih važnih aktivnih principa

\section{Gravimetric method (Weight loss method)}

The pre weighed mirror polished mild steel rods were suspended in $100 \mathrm{~mL}$ of each of the aggressive environment, $0.5 \mathrm{~N} \mathrm{HCl}$ with and different SWE concentrations. After 52 hrs immersion period, the specimens were removed, washed, dried and re-weighed using ACCULAB Electronic top loading, analytical balance. From the weight loss inhibition efficiency and corrosion rate was calculated as

$$
\begin{aligned}
& \text { Inhibition efficiency }(\%)=\left[\left(W_{0}-W_{i}\right) / W_{0}\right] \times 100 \\
& \text { Corrosion rate }(\mathrm{mmpy})=87.6 \text { W/Atd }
\end{aligned}
$$

Where $W_{0}$ and $W_{i}$ are the loss in weight of the metal sheet exposed with SWE respectively and $W$ is the moss loss. $A, t$ and $d$ respectively symbolise the exposed area of metal rod in $\mathrm{cm}^{2}$, time of exposure in $\mathrm{h}$ and density of mild steel in $\mathrm{g} / \mathrm{cm}^{3}$.

The analyze impact of temperature on the efficiency of SWE, the same gravimetric technique 
was executed at the Room temperature range of $303 \mathrm{~K}$ for $100 \mathrm{ppm}$ of SWE.

\section{Electrochemical Techniques}

Electrochemical measurements were performed in an Ivium compact-stat electrochemical measurement unit. Impedance and polarisation measurements were carried out using a classical three electrode pyrex glass cell set up with a capacity of $100 \mathrm{~mL}$. A platinum wire and a mild steel rod with $1 \mathrm{~cm}^{2}$ exposed surface area were employed as counter electrode and working electrode respectively (Figure 4). All the potential data were recorded with reference to saturated calomel electrode. Prior to each measurement, the mild steel working electrode was immersed in the test electrolyte at OCP to attain the stable state.

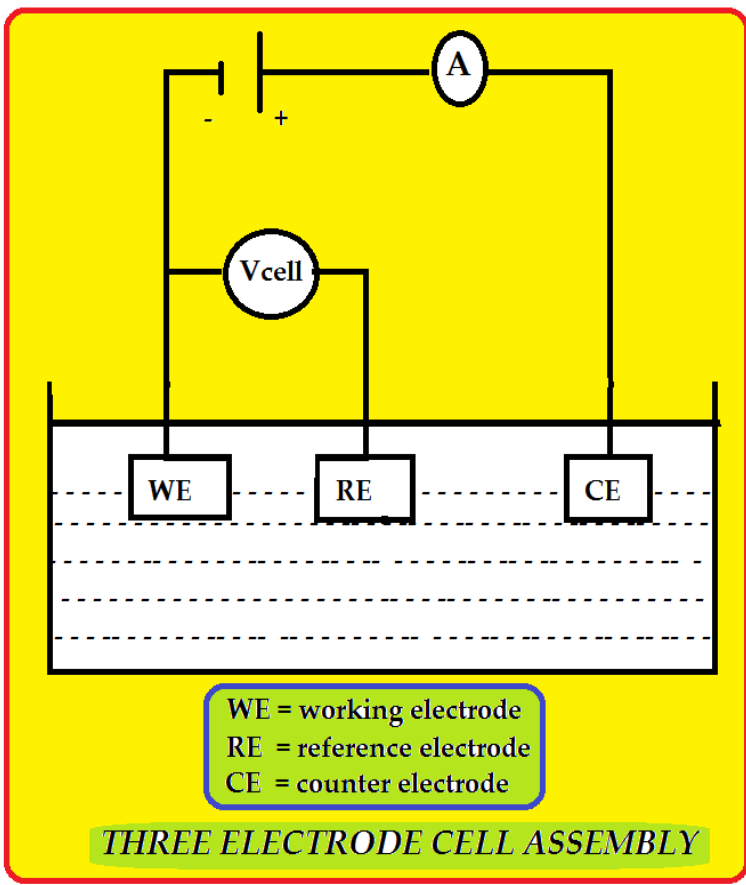

Figure 4. Three electrode cell assembly

Slika 4. Sklop ćelije sa tri elektrode

\section{Electrochemical impedance study (EIS)}

The AC impedance measurement was performed at corrosion potentials over a frequency range $0.01 \mathrm{~Hz}$ to $10 \mathrm{KHz}$ with $25 \mathrm{mV}$ peak-peak to voltage excitation per second. Electrochemical resistance, $R_{t}$ and double layer capacitance, $C_{d l}$ were computed from the $Z_{\text {real }} V s Z_{\text {imaginary }}$ plot. From $R_{t}$ data the inhibition efficiency of SWE was figured using the formula,

Inhibition efficiency $(\%)=\left[\left(R_{c t(i)}\right)-\left(R_{c t(b)}\right) /\left(R_{c t(i)}\right)\right] \times 100$ where, $R_{t(i)}$ and $R_{t(b)}$ are the electrochemical resistance in the presence and absence of SWE.

\section{Polarisation technique}

The Tafel polarization measurements were executed immediately after EIS at a sweep rate of $1 \mathrm{mV} / \mathrm{sec}$ over potential range of $-200 \mathrm{mV}$ to +200 $\mathrm{mV}$ pertaining to opn circuit potential. The corrosion potential, $\mathrm{E}_{\text {corr }}$, corrosion current, $\mathrm{I}_{\text {corr }}$ and slope for the cathodic and anodic Tafel curves, $b_{c}$ and $b_{a}$ were generated with Ivium soft software. The inhibition efficiency was computed as,

Inhibition efficiency $(\%)=\left[\left(I_{\text {corr (b) }}-I_{\text {corr (i) })}\right) / I_{\text {corr (b) }}\right]$ $x 100$

where, $\mathrm{I}_{\text {corr(b) }}$ and $\mathrm{I}_{\text {corr(i) }}$ refer the corrosion current with and without SWE.

\section{Equivalent circuit ( $R C$ circuit) diagram}

An Equivalent circuit diagram is a circuit (Figure 5 ) with both a resistor $(R)$ and a capacitor $(C)$. RC circuits are frequent element in electronic devices. They also play an important role in the transmission of electrical signals in nerve cells. The crucial parameter that describes the time dependence is the "time constant" RC. This transient response time $\mathrm{T}$, is measured in terms of $\mathrm{T}=\mathrm{R} \times \mathrm{C}$, in seconds, where $\mathrm{R}$ is the value of the resistor in ohms and $C$ is the value of the capacitor in Farads. This then forms the basis of an $\mathrm{RC}$ charging circuit were $5 \mathrm{~T}$ can also be thought of as " $5 \times \mathrm{RC}$ ".

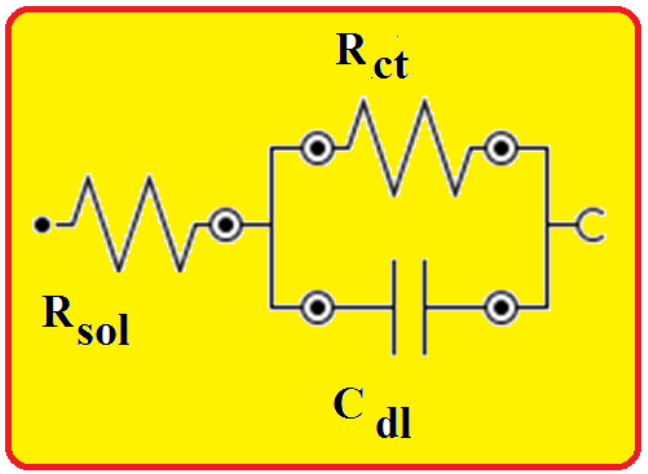

Figure 5. Electrical equivalent circuit proposed for simulate the impedance diagram

Slika 5. Predloženo električno ekvivalentno kolo za simulaciju impedansnog dijagrama

\section{RESULTS AND DISCUSSION}

\section{Method of metal weight loss}

The electrochemistry of any corroding metal in acid medium encompasses partial anodic metal dissolution and partial cathodic hydrogen evolution in accordance with the following Scheme 1. 


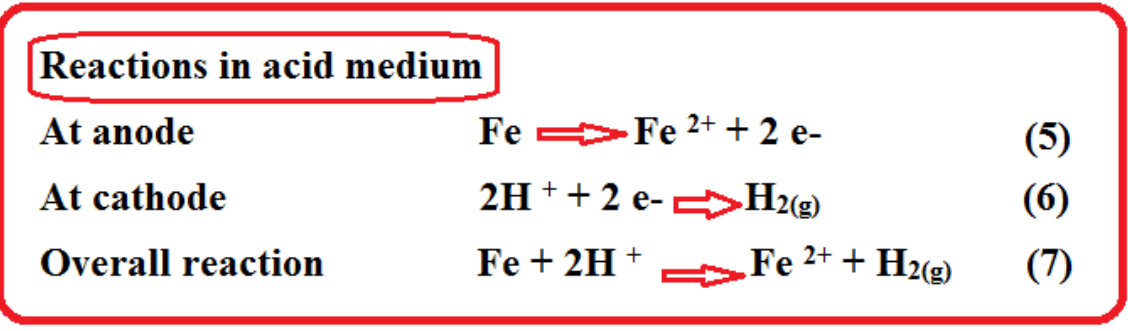

Scheme1. Anodic and Cathodic reactions in acid medium

Shema 1. Anodne i katodne reakcije u kiseloj sredini

In line with Equation 7 corrosion rate of the metal can be determined by non electrochemical methods like, weight loss, hydrogen evolution, measurement of dissolved $\mathrm{Fe}^{2+}$ concentration and change in $\mathrm{pH}$ of the electrolyte. Among these the most widely used weight loss method, due to its simplicity and reliability of the measurement, becomes the baseline method in many corrosion monitoring programs. In the present study the corrosion inhibitive ability of SWE obtained for mild steel exposed to $0.5 \mathrm{~N} \mathrm{HCl}$ composed of $100 \mathrm{ppm}$, 200ppm, 300ppm, 400ppm, 500ppm at 303K for 52 $\mathrm{h}$ (3 days) was presented. Inspection of data reveals a steady decrease in metal loss as well as corrosion rate and increase in efficiency with SWE concentration. This aspect results from the movement of SWE (sea weed extract) components from the bulk electrolyte onto the mild steel surface and adsorb as a thin film which shields the metal surface from the aggressive acid environment. The enhanced efficiency at 100 ppm concentration may be attributed to the greater coverage by more number of components of SWE on the mild steel surface thereby blocking active sites of the electrode surface at the electrode - acid interface and the corrosion occurs at the unblocked electrode sites. The increase of inhibition efficiency of mild steel alloy which controls the corrosion is calculated in Table 2. As the concentration of inhibitor increases, corrosion rate decreases and inhibition efficiency increases (Figure 6).

Table 2. Inhibition efficiency at various concentration of SW extract for mild steel corrosion in $0.5 \mathrm{HCl}$

Tabela 2. Efikasnost inhibicije pri različitim koncentracijama ekstrakta SW za koroziju mekog čelika u $0,5 \mathrm{HCl}$

\begin{tabular}{|l|c|c|c|c|}
\hline $\begin{array}{c}\text { Concent } \\
\text { ration } \\
(\mathrm{ppm})\end{array}$ & $\begin{array}{c}\text { Weight } \\
\text { loss } \\
(\mathrm{g})\end{array}$ & $\begin{array}{c}\text { Corrosio } \\
\text { n Rate } \\
(\mathrm{mmpg})\end{array}$ & $\begin{array}{c}\text { Surface } \\
\text { Coverage } \\
(\theta)\end{array}$ & IE \% \\
\hline Blank & 0.1734 & 5.47 & - & - \\
\hline $100 \mathrm{ppm}$ & 0.0197 & 0.62 & 0.8864 & 88.64 \\
\hline $200 \mathrm{ppm}$ & 0.0188 & 0.59 & 0.8916 & 89.16 \\
\hline $300 \mathrm{ppm}$ & 0.0131 & 0.41 & 0.9245 & 92.45 \\
\hline $400 \mathrm{ppm}$ & 0.0038 & 0.12 & 0.9781 & 97.81 \\
\hline $500 \mathrm{ppm}$ & 0.0013 & 0.04 & 0.9925 & 99.25 \\
\hline
\end{tabular}

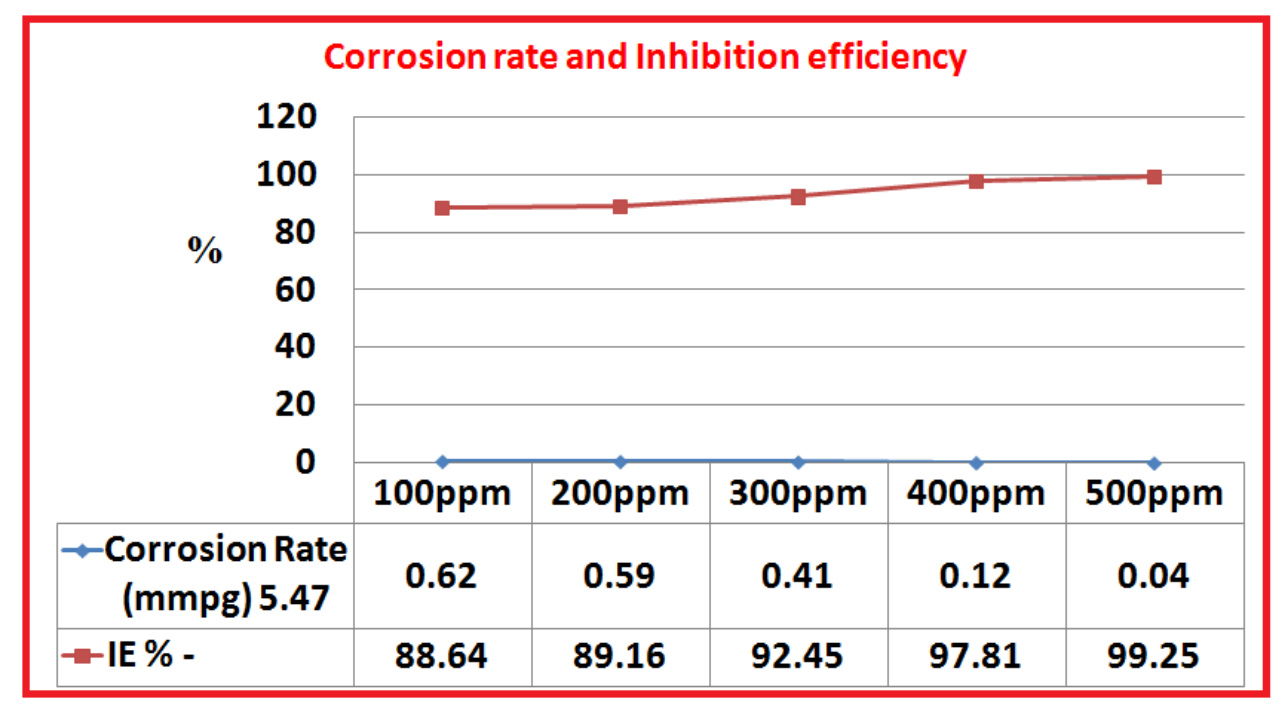

Figure 6. Corrosion rate and inhibition efficiency

Slika 6. Brzina korozije i efikasnost inhibicije 


\section{Langmuir Adsorption Isotherm}

A plot of $\mathrm{C}$ vs $\mathrm{C} / \theta$ gives a straight line is obtained with very high correlation coefficient $\mathrm{R}^{2}$ (0.997). This indicates that the adsorption of active principle molecules on the metal surface takes place by Langmuir adsorption isotherm (Figure7). There is formation of monolayers. The $\mathrm{C}$ (concentration in $\mathrm{ppm}$ ) and $\mathrm{C} / \theta$ values are given in Table 3.

Table 3. The $C$ (concentration in $\mathrm{ppm}$ ) and $\mathrm{C} / \mathrm{\theta}$ values for Langmuir adsorption isotherm

Tabela 3. Vrednosti C (koncentracija u ppm) i C/O za Langmuirovu adsorpcionu izotermu

\begin{tabular}{|c|c|c|}
\hline C, ppm & $\begin{array}{c}\text { Surface } \\
\text { coverage } \theta\end{array}$ & $\mathrm{C} / \theta$ \\
\hline 100 & 0.8864 & 113 \\
\hline 200 & 0.8916 & 224 \\
\hline 300 & 0.9245 & 325 \\
\hline 400 & 0.9781 & 409 \\
\hline 500 & 0.9925 & 504 \\
\hline
\end{tabular}

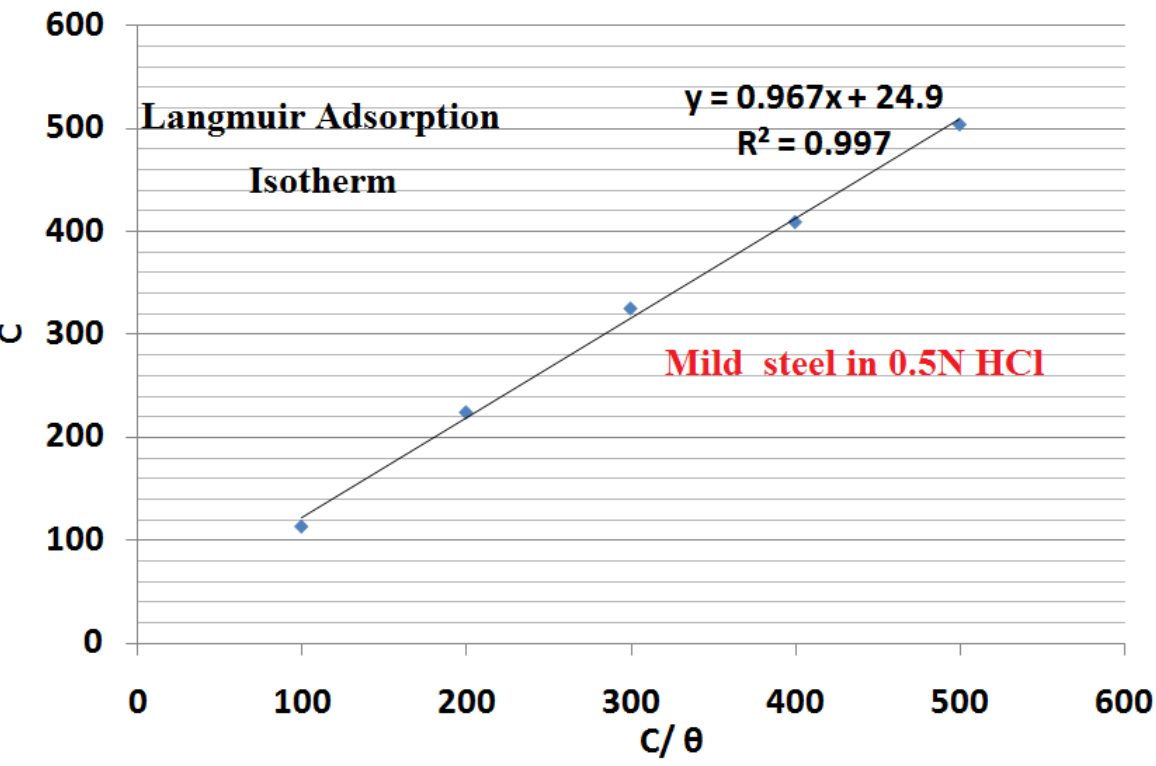

Figure 7. Langmuir adsorption isotherm

Slika 7. Langmuir-ova adsorpciona izoterma

\section{Electrochemical Measurements}

Electrochemical studies such as polarization study and AC Impedance spectra have been widely used in corrosion inhibition study [12-16]. If there is corrosion protection, linear polarization resistance increases, corrosion current decreases, charge transfer resistance increases, double layer capacitance decreases, impedance value increases and phase angle value increases.

Electrochemical impedance spectroscopy (EIS) (AC Impedance spectra)

EIS is a sophisticated technique, widely employed to study the corrosion behaviour of mild steel and also the adsorption phenomena. EIS measurements of mild steel electrode was performed at is open circuit in blank $0.5 \mathrm{~N} \mathrm{HCl}$ electrolyte and also in the presence of SW extract concentrations. The corresponding Nyquist, Bode modulus and phase angle representations of EIS are portrayed in Figures 8-10, for mild steel after the addition of SW extract.
Table 4. Corrosion parameters for mild steel at various concentrations of SW extract by Impedance method for $52 \mathrm{~h}$

Tabela 4. Parametri korozije za meki čelik pri različitim koncentracijama SW ekstrakta metodom impedance tokom $52 \mathrm{~h}$

\begin{tabular}{|c|c|c|c|}
\hline $\begin{array}{c}\text { Inhibitor } \\
\text { ppm }\end{array}$ & $\begin{array}{c}\mathrm{OCP} \\
\mathrm{V}\end{array}$ & $\begin{array}{c}\mathrm{R}_{\mathrm{ct}} \\
\mathrm{Ohmcm}^{2}\end{array}$ & $\begin{array}{c}\mathrm{C}_{\mathrm{dl}} \\
\mathrm{mF} / \mathrm{cm}^{2}\end{array}$ \\
\hline Blank & -0.389 & 11.174 & 19 \\
\hline $100 \mathrm{ppm}$ & -0.385 & 17.721 & 17.3 \\
\hline $200 \mathrm{ppm}$ & -0.379 & 34.945 & 17.1 \\
\hline $300 \mathrm{ppm}$ & -0.372 & 27.421 & 16.9 \\
\hline $400 \mathrm{ppm}$ & -0.368 & 92.31 & 16.7 \\
\hline $500 \mathrm{ppm}$ & -0.355 & 94.31 & 16.5 \\
\hline
\end{tabular}

Only a single depressed capacitive semicircle is seen in all the cases at high frequency with deviation of their centers from the real axis. The EIS parameters, charge transfer resistance $\left(R_{c t}\right)$ 
and capacitance of the double layer $\left(C_{d 1}\right)$ were simulated by the simple equivalent circuit. Charge transfer resistance, $R_{c t}$ indicates the degree of electron transfer across the surface. It is inversely proportional to corrosion rate. Efficiency of inhibitor is computed from charge transfer resistance in the presence $\left(R_{c t(i)}\right)$ and absence $\left(R_{c t(b)}\right)$ of inhibitor as

Inhibition efficiency $(\%)=\left[\left(R_{c t(i)}\right)-\left(R_{c t(b)}\right) /\left(R_{c t(i)}\right)\right] \times 100$

As presented in Table $4, \mathrm{R}_{\mathrm{ct}}$ values increased with extract concentration which leads to the reduction in mild steel corrosion rate and increase in inhibition efficiency. SW extract shows greater efficiency in $0.5 \mathrm{~N} \mathrm{HCl}$. The higher efficiency in $\mathrm{HCl}$ indicates greater adsorption of inhibitor. This might be due to the specific tendency of $\mathrm{Cl}^{-}$ions to strongly adsorb on the steel surface. It is observed from the Figures 8-10 that as the concentration of inhibitor increases, impedance value increases and also phase angle value increases (Figure 11).

Corrosion parameters from AC impedance spectra are compared in Figure 12. The inhibition efficiency calculated from $R_{t}$ values (equation 3 ) is $88.16 \%$, calculated for the $500 \mathrm{ppm}$ of inhibitor system.

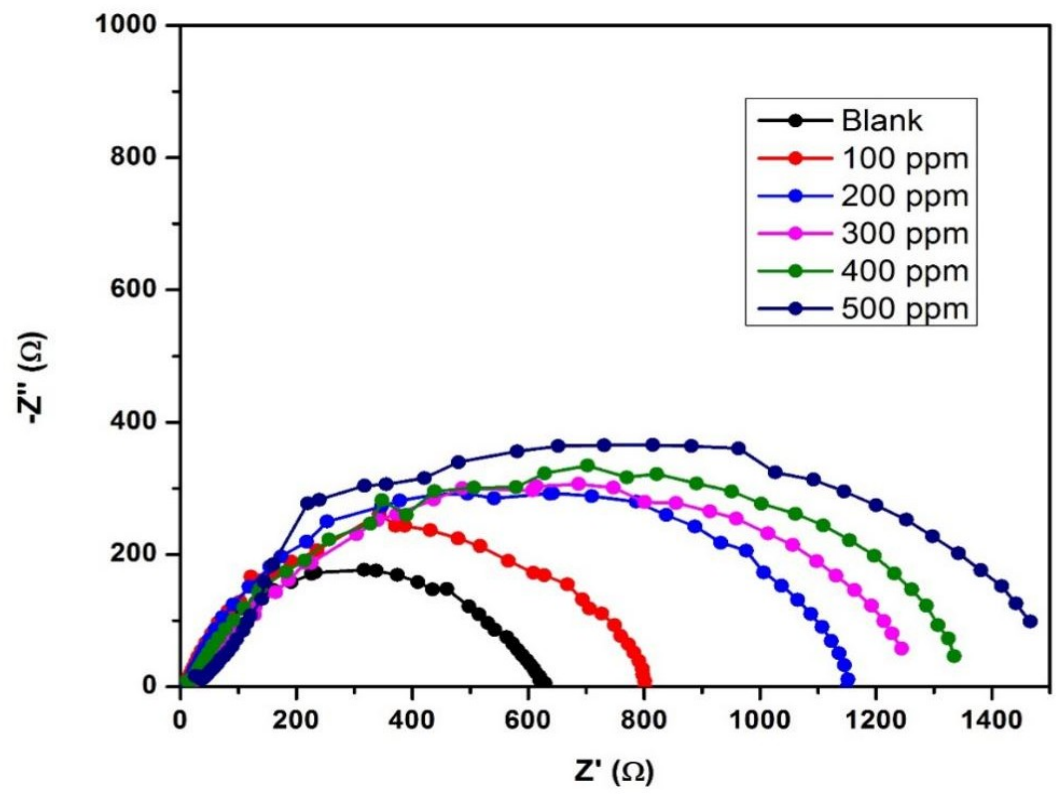

Figure 8. Nyquist plots

Slika 8. Nyquist-ove krive

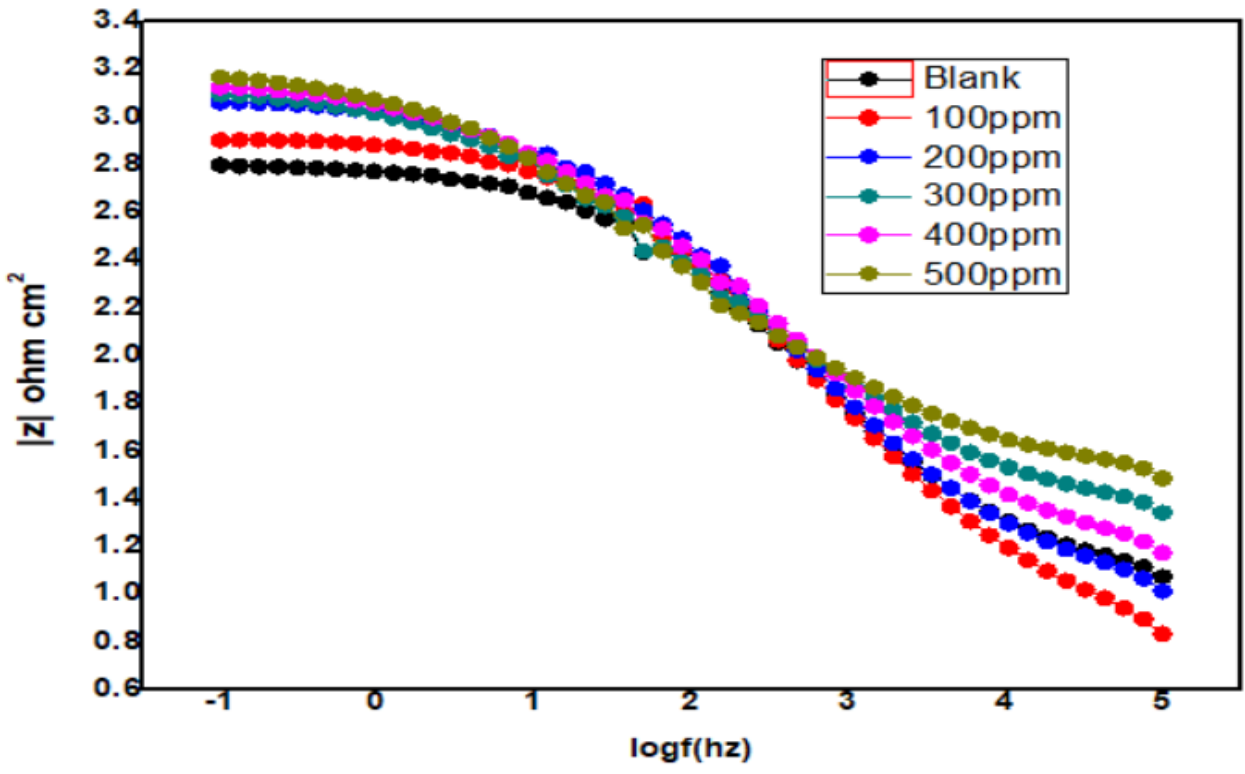

Figure 9. Bode impedance plots

Slika 9. Bode-ove krive impedance 


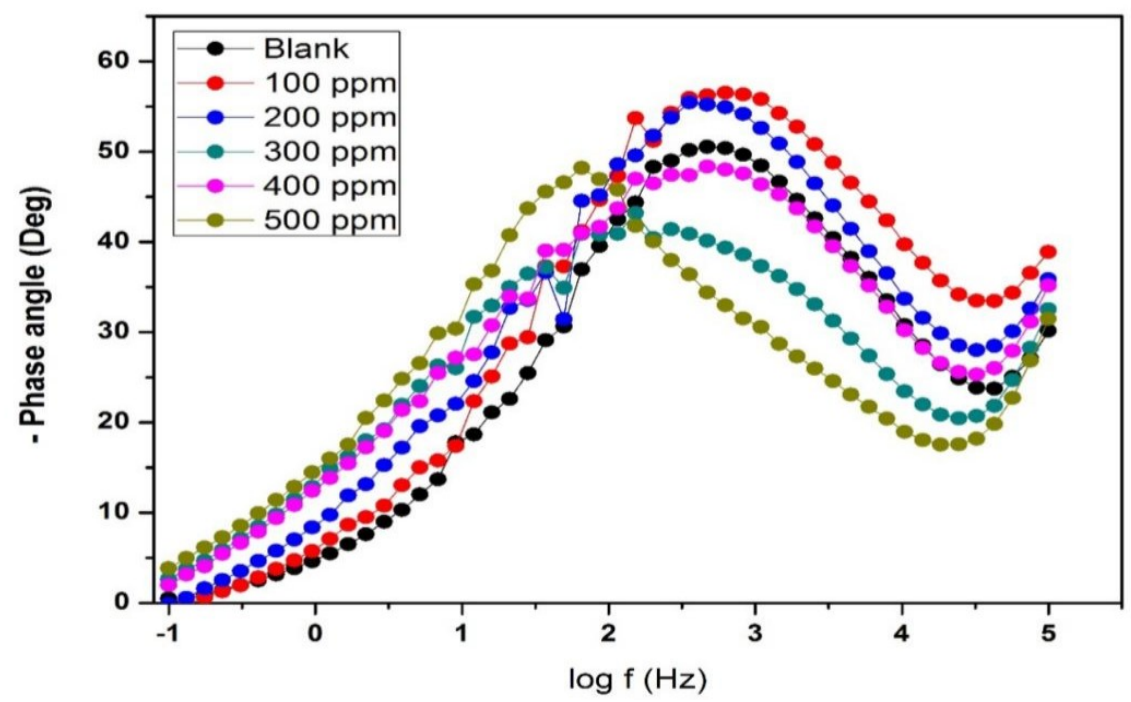

Figure 10. Bode phase angle plots

Slika 10. Bode-ove fazne krive

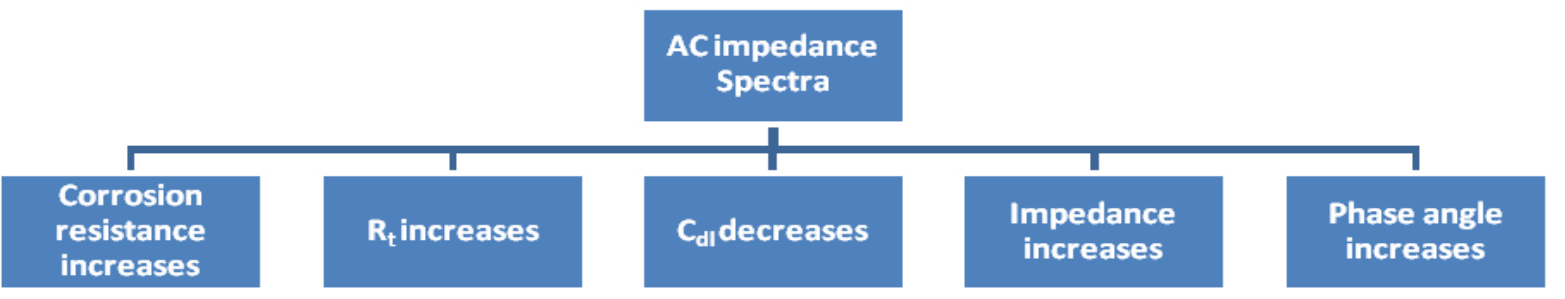

Figure 11. Correlation among corrosion parameters in AC impedance spectra

Slika 11. Korelacija parametara korozije u spektrima impedance naizmenične struje

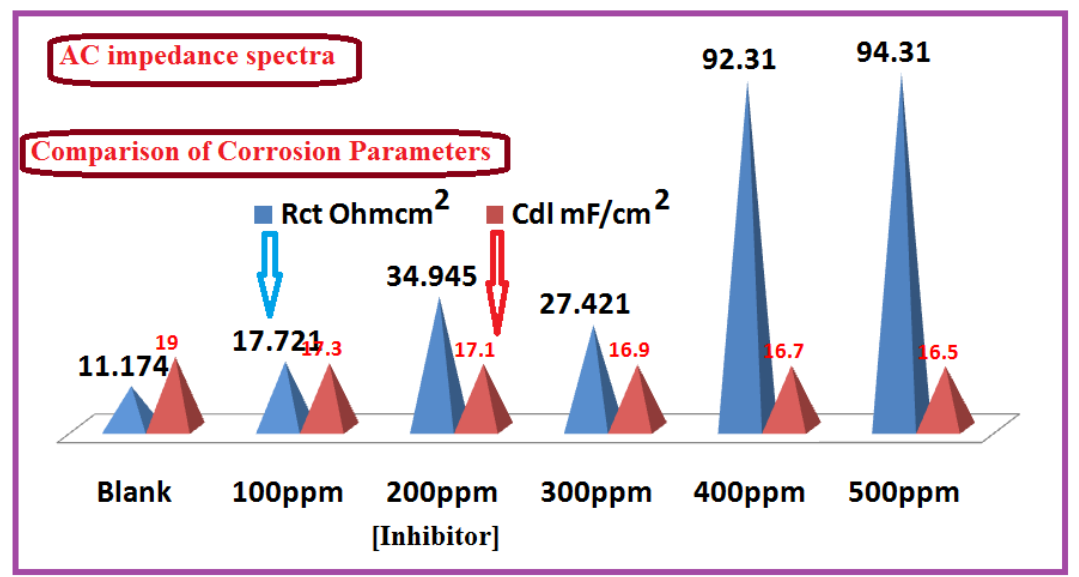

Figure 12. Comparison of corrosion parameters from AC impedance spectra

Slika 12. Poređenje parametara korozije iz spektra impedance naizmenične struje

Tafel polarization studies Tafel potentiodynamic polarization study is used to explore the corrosion inhibition $(\mathrm{Cl})$ of alloys and metals. When corrosion rate decreases, there is increase in linear polarization resistance (LPR) and decrease of corrosion current $\left(I_{\text {corr }}\right)$ (Figure 13).
Hence, when anodic reaction is predominantly controlled, there is shift in corrosion potential $\left(E_{\text {corr }}\right)$ to anodic side-noble side (less -ve side or +ve side) and when cathodic reaction is predominantly controlled, there is shift of $\mathrm{E}_{\text {corr }}$ to active side (more -ve side). If both, anodic and cathodic reactions are predominantly controlled, then the shift in $\mathrm{E}_{\text {corr }}$ is less (within $50 \mathrm{mV} /$ decade). Figure 14 illustrates 
the polarization curves (Tafel plots) of MS alloy evaluated in different concentrations of inhibitor at a room temperature. To study the effect of SWE (Seaweed Extract) on the corrosion process of mild steel, anodic and cathodic polarization behaviour in $0.5 \mathrm{~N} \mathrm{HCl}$ was recorded for different inhibitor concentrations (Table 5).

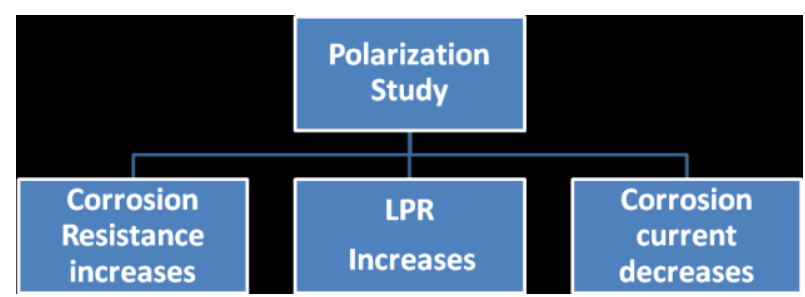

Figure 13. Correlation among corrosion parameters of polarisation study

Slika 13. Korelacija među parametrima korozije pri polarizacionoj studiji

Table 5. Corrosion parameters of MS Alloy in SW Extract Solution in $52 \mathrm{~h}$ for Polarization Study

Tabela 5. Parametri korozije MS legure u rastvoru ekstrakta SW u toku $52 \mathrm{~h}$ za studiju polarizacije

\begin{tabular}{|c|c|c|c|}
\hline $\begin{array}{c}\text { Inhibitor } \\
\mathrm{ppm}\end{array}$ & $\begin{array}{c}\text { Ecorr } \\
\mathrm{mV} / \mathrm{SCE}\end{array}$ & $\begin{array}{c}\text { LPR } \\
\text { Ohmcm }\end{array}$ & $\begin{array}{c}\text { Icorr } \\
\mathrm{A} / \mathrm{cm}^{2}\end{array}$ \\
\hline Blank & -533 & 49.051 & $2.66 \times 10^{-03}$ \\
\hline $100 \mathrm{ppm}$ & -550 & 194.15 & $0.327 \times 10^{-03}$ \\
\hline $200 \mathrm{ppm}$ & -548 & 463.25 & $0.300 \times 10^{-03}$ \\
\hline $300 \mathrm{ppm}$ & -540 & 868.0 & $0.162 \times 10^{-03}$ \\
\hline $400 \mathrm{ppm}$ & -520 & 1493.9 & $0.0117 \times 10^{-03}$ \\
\hline $500 \mathrm{ppm}$ & -514 & 1950.3 & $0.00293 \times 10^{-03}$ \\
\hline
\end{tabular}

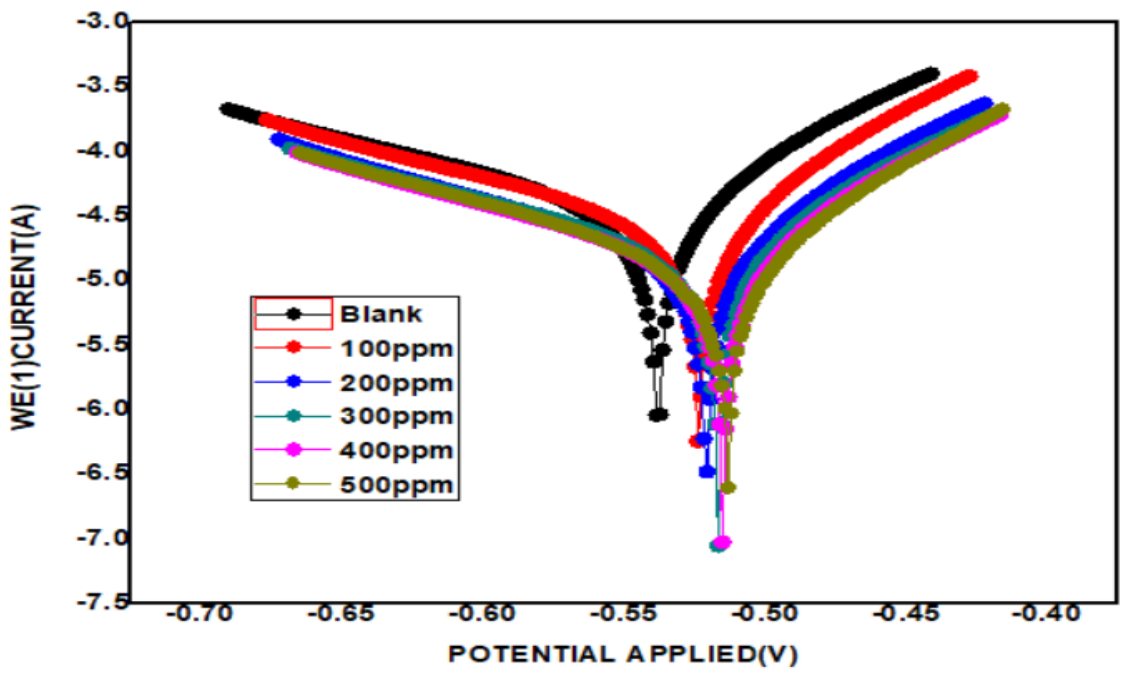

Figure14. Tafel behavior of mild steel in $0.5 \mathrm{~N} \mathrm{HCl}$ with different concentrations of SWE for $52 \mathrm{~h}$ Slika 14. Tafel-ove krive mekog čelika u $0,5 \mathrm{~N} \mathrm{HCl}$ sa različitim koncentracijama SWE tokom $52 \mathrm{~h}$

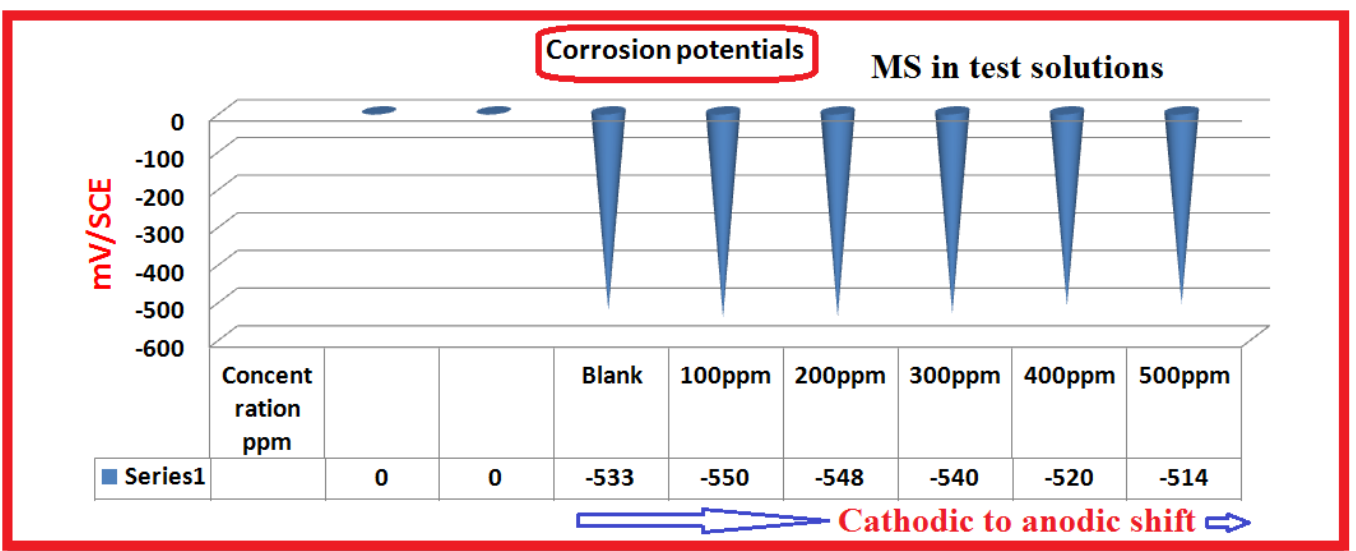

Figure15. The corrosion potential

Slika 15. Potencijal korozije 
Corrosion parameters of MS Alloy in SW Extract Solution for $52 \mathrm{~h}$ obtained by Polarization Study

When MS Alloy immersed in $0.5 \mathrm{~N} \mathrm{HCl}$ medium for $52 \mathrm{~h}$, LPR value is $49.051 \mathrm{Ohmcm}^{2}$. The corrosion current $\left(\mathrm{I}_{\text {corr }}\right)$ value is $2.66 \times 10^{-03} \mathrm{~A} / \mathrm{cm}^{2}$. The corrosion potential ( $E_{\text {corr }}$ ) value is $-533 \mathrm{mV}$ vs SCE.

When MS Alloy immersed in $0.5 \mathrm{~N} \mathrm{HCl}$ medium for $52 \mathrm{~h}$, in presence of inhibitor (500ppm), LPR value is $1950.7 \mathrm{Ohmcm}^{2}$. The corrosion current $\left(I_{\text {corr }}\right)$ value is $0.293 \times 10^{-5} \mathrm{~A} / \mathrm{cm}^{2}$. The corrosion potential $\left(\mathrm{E}_{\text {corr }}\right)$ value is $-514 \mathrm{mV}$ vs SCE. Thus the polarization study leads to the conclusion that corrosion resistance of $\mathrm{MS}$ in $0.5 \mathrm{~N} \mathrm{HCl}$ medium increases in presence of inhibitor (500ppm). The corrosion potential shifts to the anodic side (Figure15). There is increases in LPR value (Figure 16) and decrease in corrosion current value (Figure 17). The corrosion inhibition efficiency calculated from polarization parameters (equation 4) is $97.48 \%$.

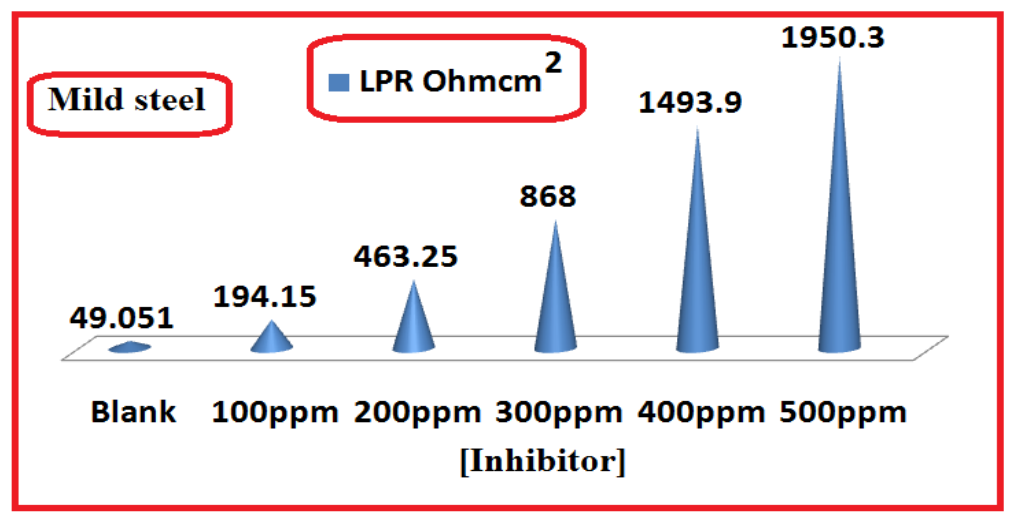

Figure 16. Comparison of $L P R$ values

Slika 16. Poređenje vrednosti LPR -a

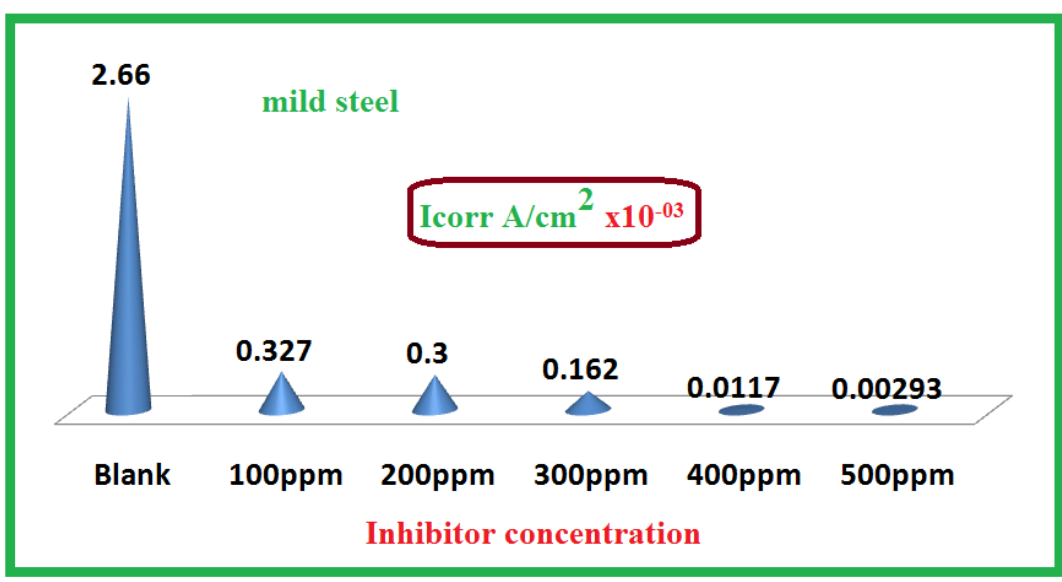

Figure 17. Comparison of corrosion current values

Slika 17. Poređenje vrednosti struje korozije

\section{CONCLUSION}

- An alcoholic extract of a sea weed Sargassum muticum has been used to control corrosion of mild steel in $0.5 \mathrm{~N} \mathrm{HCl}$.

- Weight loss method and Electrochemical studies have been used in this study. Weight loss study reveals that $500 \mathrm{ppm}$ of the inhibitor offers 99.25\% inhibition efficiency.

- Polarization study reveals that the inhibitor functions as an anodic inhibitor at higher concentration. The AC impedance spectra confirm the formation of a protective film on the metal surface. Adsorption of inhibitor molecules on the metal surface follows Langmuir adsorption isotherm.

\section{REFERENCES}

[1] S.A.Umoren, M.M.Solomon, I.B.Obot, R.K.Suleiman (2018) Comparative studies on the corrosion inhibition efficacy of ethanolic extracts of date palm leaves and seeds on carbon steel corrosion in $15 \%$ $\mathrm{HCl}$ solution, Journal of Adhesion Science and Technology, 32(17), 1934-1951. 
[2] F.El-Taib Heakal, M.A.Deyab, M.M.Osman, A.E. Elkholy (2018) Performance of Centaurea cyanus aqueous extract towards corrosion mitigation of carbon steel in saline formation water, Desalination, 425, 111-122.

[3] R.S.Dos Santos, M.R.Cordeiro, R.F.B. D'Elia (2017) A study of the gorse aqueous extract as a green corrosion inhibitor for mild steel in $\mathrm{HCl}$ aqueous solution, Trindade, Green Chemistry Letters and Reviews, 10(4), 444-454.

[4] P.Parthipan, J.Narenkumar, P.Elumalai, A.Agrawal, A.Rajasekar (2017) Neem extract as a green inhibitor for microbiologically influenced corrosion of carbon steel API 5LX in a hypersaline environments, Journal of Molecular Liquids, 240, 121-127.

[5] M.Tezeghdenti, N.Etteyeb, L.Dhouibi, O.Kanoun, A.Al-Hamri (2017) Natural products as a source of environmentally friendly corrosion inhibitors of mild steel in dilute sulphuric acid: Experimental and computational studies, Protection of Metals and Physical Chemistry of Surfaces, 53(4),753-764.

[6] S.O.Ajeigbe, N.Basar, M.A.Hassan, M.Aziz (2017) Optimization of corrosion inhibition of essential oils of Alpinia galanga on mild steel using Response Surface Methodology, ARPN Journal of Engineering and Applied Sciences, 12(9), 2763-2771.

[7] N.A.Shehata, M.F.Saleh, A.Ghany, R.M. El Hosary (2017) Novel corrosion inhibitors for acidizing oil wells, Materials and Corrosion, 68(3), 355-360.

[8] G.Pustaj, F.Kapor, S.Jakovljević (2017) Carbon dioxide corrosion of carbon steel and corrosion inhibition by natural olive leaf extract, [Die Kohlendioxid-Korrosion von Kohlenstoffstahl und die Korrosionshemmung durch natürlichen Olivenblattextrakt], Materialwissenschaft und Werkstofftechnik, 48(2), 122-138.

[9] O.Ajayi, N.Everitt, K.T.Voisey (2017) Corrosion inhibition of mild steel in $15 \mathrm{wt} . \% \mathrm{HCl}$ by durum wheat, Eurocorr, The Annual Congress of the European Federation of Corrosion, 20th International Corrosion Congress and Process Safety Congress.

[10] S.Wu, B.Qiu, C.Fu, X.Wang (2017) Inhibition effect of tangerine peel extract on $\mathrm{J} 55$ Steel in $\mathrm{CO}_{2}$ saturated $3.5 \mathrm{wt} . \% \mathrm{NaCl}$ solution, International Journal of Electrochemical Science, 12(12), 1119511211.

[11] https://en.wikipedia.org/wiki/Sargassum_muticum

[12] M.Cenoui, I.Himer, R.Touir, M.Ebn Touhami, A.Dermaj, N.Hajaji, H.El Kafssaoui (2010) Synergistic influence of molybdate ions on the inhibition of corrosion and scale of ordinary steel in cooling water system by new organic compound, Zastita materijala, 51(1), 3-10

[13] N.Antony, H.Benita Sherine, S.Susai Rajendran (2010) Investigation of the inhibiting effect of nano film by sodium meta silicate- Zn2+ system on the corrosion of carbon steel in neutral chloride solution, Zastita materijala, 51(1), 11-18

[14] S.Rajendran, T.S.Muthumegala, M.Pandiarajan, P.Nithya Devi, A.Krishnaveni, J. Jeyasundari, B.Narayana Samy, N.Hajara Beevi (2011) Corrosion resistance of SS316L in simulated concrete pore solution in presence of trisodium citrate, Zastita materijala, 52(2), 85-89.

[15] A.S.Fouda, G.Y.Elewady, A.EL-Askalany, K.Shalabi (2010) Inhibition of aluminum corrosion in hydrochloric acid media by three Schiff base compounds, Zastita materijala, 51(4), 205-219.

[16] S.Rajendran, V.Sribharathy, A.Krishnaveni, J.Jeyasundari, J.Sathiyabama, T.S.Muthumegala, M.Manivannan (2011) Inhibition effect of self assembled films formed by adipic acid molecules on carbon steel surface, Zastita materijala, 52(3), 163172.

\title{
IZVOD
}

\section{INHIBICIJA KOROZIJE MEKOG ČELIKA ALKOHOLNIM EKSTRAKTOM ALGI SARGASSUM MUTICUM}

Alkoholni ekstrakt morske trave Sargassum muticum korišćen je za kontrolu korozije mekog čelika u $0,5 \mathrm{~N} \mathrm{HCl}$. U ovoj studiji su korišćene metode gubitka težine i elektrohemijske studije. Studija gubitka težine otkriva da 500 vodppm inhibitora daje 99,25\% efikasnost inhibicije. Studija polarizacije otkriva da inhibitor funkcioniše kao anodni inhibitor u većoj koncentraciji. Spektar impedanse naizmenične struje potvrđuje stvaranje zaštitnog filma na površini metala. Adsorpcija molekula inhibitora na površini metala prati Langmuirovu izotermu adsorpcije.

Ključne reči: inhibicija korozije, meki čelik, morski korov, Sargassum muticum, elektrohemijske studije, Langmuirova izoterma adsorpcije, kiseli medijum

\author{
Naučni rad \\ Rad primljen: 01. 08. 2021 \\ Rad korigovan: 20. 09. 2021. \\ Rad prihvaćen: 25. 09. 2021. \\ Rad je dostupan na sajtu: www.idk.org.rs/casopis
}

(c) 2021 Authors. Published by Engineering Society for Corrosion. This article is an open access article distributed under the terms and conditions of the Creative Commons Attribution 4.0 International license (https://creativecommons.org/licenses/by/4.0/) 